\title{
FISH SPECIES AND SIZE DISTRIBUTION AND ABUNDANCE IN DIFFERENT AREAS IN LAKE VICTORIA, TANZANIA
}

\author{
AI Chande ${ }^{1}$ and HA Mhitu ${ }^{2}$ \\ Tanzania Fisheries Research Institute \\ ${ }^{1}$ PO Box 9750, Dar es Salaam \\ ${ }^{2}$ PO Box 78850, Dar es Salaam \\ E - mail: chande15@hotmail.com, mhitu@yahoo.co.uk
}

\begin{abstract}
The study was carried out to investigate fish species distribution and abundance in different areas and size structure variations according to depth in Lake Victoria, Tanzania. Data were collected using a bottom trawl net during rainy and dry seasons in 2002. The results show that there were significant differences in catch rates between rainy and dry seasons $\left(F_{(12,12)}=2.69 ; p\right.$ $<0.05)$. The rainy season recorded higher catch rates $(36.25-106.61 \mathrm{~kg} / \mathrm{hr})$ than during the dry season $(14.30$ - $67.90 \mathrm{~kg} / \mathrm{hr})$. The haplochromines catch rates were higher during the dry season $(11.08 \mathrm{~kg} / \mathrm{hr})$ than during the rainy season $(7.72 \mathrm{~kg} / \mathrm{hr})$, however, the differences were not significant $\left(\chi^{2}=0.60, d f=1, p>0.05\right)$. The distribution of the fish species in different areas recorded a significant difference during the dry season $(Q=18.254, d f=8, P<0.001)$, while during the rainy season the difference was not significant $(Q=10.667, d f=8, P>0.001)$. Moreover, the results show that small individuals dominated in shallow waters at a mode ranging between $15 \mathrm{~cm}$ and $25 \mathrm{~cm}$ TL. Larger individuals dominated in deep waters recording a mode at $45.5 \mathrm{~cm}$ TL. The study therefore, suggests that in order to have a sustainable fishery, L. niloticus should actively be exploited at depths greater than $20 \mathrm{~m}$ where there are larger and mature individuals.
\end{abstract}

\section{INTRODUCTION}

Before the Nile perch got established in Lake Victoria, the fish fauna was dominated by a diversified, probably monophyletic species flock of haplochromine cichlids. The fish species flock was comprised of more than 500 haplochromine species excluding other indigenous fish species (Meyer et al. 1990). The fish species occupied a great variety of niches (Witte et al. 1992).

Over the last two decades several changes in the lake ecosystem have been observed. Exceptionally high yields of fish were observed during the 1980's as a result of the introduction of the Nile perch (Lates niloticus) and other environmental impacts within the entire ecosystem. At the same time species diversity was declining (Mkumbo 2002). It is anticipated that a number of reasons are behind the decline in fish species diversity. For example, haplochromines declined or were eliminated in some areas largely due to predation and overfishing (Ogutu Ohwayo 1988). The indigenous tilapiines including Oreochromis esculentus and $O$. variabilis were eliminated as a result of trophic interactions with introduced species mainly $O$. niloticus, Tilapia zillii and $O$. leucostictus (Kudhongania 1972). At present the lake is characterized by fishery of a few species comprising mainly of L. niloticus, Rastrineobola argentea and Oreochromis niloticus (Goudswaard and Ligtvoet 1988).

Environmental changes have also been reported to play some role in the decline of fish species diversity. For example, the invasion of the water hyacinth, Eichhornia crassipes reported in the late 1980's which has been associated with many environmental changes (Kaufman 1992). Weed mats of E. crassipes covering the water surface destroy rooted or floating macrophytes as well as breeding and nursery grounds of some fish species. These weed mats not only obscure light from penetrating 
to benthic or demersal areas of the lake but are also a cause of localized deoxygenation in the area hence causing some species to abandon the areas (Goudswaard \& Witte 1985). Decaying of dead leaves result in the release of poisonous gases like ammonia and hydrogen sulphide which are deleterious to the survival of fauna in the areas (Goudswaard \& Witte 1985, Mugidde 1993).

Studies have revealed that the fish species which were feared to have disappeared have shown some signs of recovery (Bayona et al. 2003). The recovering species include; the haplochromines, Schilbe intermedius, Brycinus species, Bagrus docmak, Clarias gariepinus, Synodontis victoriae and $S$. afrofischeri. There is scarce information on the distribution and abundance of fish species in different areas and the distribution of different sizes according to depth on the Tanzania side of Lake Victoria. It was therefore, the aim of this study to provide information on fish species distribution and abundance in different areas and size structure variations according to depth.

\section{MATERIALS AND METHODS}

\section{Study Area}

The study was carried out in Lake Victoria, Tanzania in nine stations namely; Magu Bay, Bulamba, Lamadi, Baumann Gulf, Shirati Bay, Mori Bay, Mara Bay, Rubafu Bay and Mwanza Gulf. The lake is situated on the East African plateau at $1134 \mathrm{~m}$ above sea level. The climate is equatorial with two wet seasons, one between October and December, the other between February and April.

\section{Sample and Data Collection}

Samples were collected during January/February and December which constituted the rainy season and July/August, 2002 which constituted the dry season (Waya \& Chande 2004). The samples were collected using a stern trawler RV TAFIRI II with $150 \mathrm{HP}$ operating a bottom trawl net of $38 \mathrm{~mm}$ mesh cod end.
Sampling areas were two depth ranges one less than $20 \mathrm{~m}$ and the other between 20 and $30 \mathrm{~m}$. The range of $20-30 \mathrm{~m}$ included Shirati and Rubafu areas. Each trawl operation took 30 minutes and on retrieval of the net, big fish were first sorted out. The sample was then sorted into different fish species and weighed to obtain the sample weight. The weights were used to calculate catch rates $(\mathrm{kg} / \mathrm{hr})$. Individual length of Lates niloticus from the two depth ranges were recorded and used to generate length frequency distributions. During sampling, data on physico - chemical parameters from the same environment were also recorded. Temperature and dissolved oxygen were measured using Wagtech Portable probes that permitted measurement of these parameters on site. Transparency was measured using a secchi disc. Measurement of chemical parameters (concentrations of ammonia, nitrate, nitrite and phosphate) was done in the laboratory using the Palintest Photometer 5000 (Kulekana 2003).

\section{Data Analysis}

The distribution of fish species in different stations for both wet and dry seasons was compared using Cochran's Q test (Zar 1984). The differences in catch rates $(\mathrm{kg} / \mathrm{hr})$ of different fish species between rainy season and dry season were tested using analysis of variance. The differences in the catch rates of haplochromines between rainy and dry seasons were tested using Chi-square $\left(\chi^{2}\right)$.

\section{RESULTS}

Seasonal distribution and abundance (catch rates) of fish species in different areas

Tables 1 and 2 present distribution and catch rates of different fish species in different areas during rainy and dry seasons. The results show that all fish species which were encountered during the rainy season were also recorded during the dry season in varying magnitudes. The results showed a significant difference during the dry season $(\mathrm{Q}=18.254$, df $=8, \mathrm{P}<0.001)$, while during the rainy season there was no 
significant difference $(\mathrm{Q}=10.6667, \mathrm{df}=8$,

$\mathrm{P}>0.001)$.

Table 1: Distribution and catch rates $(\mathrm{kg} / \mathrm{hr})$ of fish species from trawl catches during January/February (rainy season), 2002 in Lake Victoria, Tanzania.

\begin{tabular}{|c|c|c|c|c|c|c|c|c|c|c|}
\hline \multicolumn{11}{|l|}{ Species } \\
\hline & \multicolumn{10}{|c|}{ Sites } \\
\hline & $\begin{array}{l}\text { Magu } \\
\text { bay }\end{array}$ & Lamadi & Bulamba & $\begin{array}{l}\text { Baumann } \\
\text { gulf }\end{array}$ & $\begin{array}{l}\text { Shirati } \\
\text { bay }\end{array}$ & $\begin{array}{l}\text { Mori } \\
\text { bay }\end{array}$ & $\begin{array}{l}\text { Mara } \\
\text { bay }\end{array}$ & $\begin{array}{l}\text { Rubafu } \\
\text { bay }\end{array}$ & $\begin{array}{l}\text { Mwanza } \\
\text { gulf }\end{array}$ & Total \\
\hline Lates niloticus & 11.50 & 26.34 & 80.04 & 23.05 & 34.15 & 35.90 & 88.50 & 50.17 & 61.80 & 411.45 \\
\hline $\begin{array}{l}\text { Oreochromis } \\
\text { niloticus }\end{array}$ & - & 9.65 & 2.66 & 25.05 & 2.67 & - & 17.40 & 3.16 & - & 60.59 \\
\hline $\begin{array}{l}\text { Synodontis } \\
\text { victoriae }\end{array}$ & .35 & .18 & .27 & - & - & - & .01 & .02 & 0.29 & 1.12 \\
\hline S. afrofischeri & - & .22 & .01 & .02 & - & .01 & - & .02 & 0.10 & 0.38 \\
\hline $\begin{array}{l}\text { Protopterus } \\
\text { aethiopicus }\end{array}$ & 33.0 & - & - & 4.0 & - & - & - & - & 12.70 & 49.70 \\
\hline $\begin{array}{l}\text { Schilbe } \\
\text { intermedius }\end{array}$ & .50 & .05 & .76 & - & .06 & .05 & .57 & 0.07 & 0.47 & 2.53 \\
\hline $\begin{array}{l}\text { Clarias } \\
\text { gariepinus }\end{array}$ & 11.0 & - & - & - & - & - & - & 3.30 & - & 14.30 \\
\hline $\begin{array}{l}\text { Bagrus } \\
\text { docmak }\end{array}$ & .52 & - & - & - & - & - & - & - & - & 0.52 \\
\hline $\begin{array}{l}\text { Brycinus } \\
\text { sadleri }\end{array}$ & - & 1.22 & .02 & .01 & - & - & - & - & - & 1.25 \\
\hline B. jacksonii & - & .86 & .01 & - & - & - & - & - & - & 0.87 \\
\hline $\begin{array}{l}\text { Barbus } \\
\text { altianalis }\end{array}$ & .01 & - & .01 & - & - & .03 & - & - & 0.01 & 0.06 \\
\hline $\begin{array}{l}\text { Labeo } \\
\text { victorianus }\end{array}$ & - & - & - & - & - & - & - & - & 0.27 & 0.27 \\
\hline Haplochromines & 3.35 & 1.0 & 1.12 & .06 & .23 & .26 & .13 & 0.94 & 0.63 & 7.72 \\
\hline Total & 59.61 & 39.42 & 84.70 & 52.19 & 37.11 & 36.25 & 106.61 & 57.56 & 76.27 & 550.76 \\
\hline
\end{tabular}

Table 2: Distribution and catch rates $(\mathrm{kg} / \mathrm{hr})$ of fish species from trawl catches during July/August (dry season), 2002 in Lake Victoria, Tanzania.

\begin{tabular}{|c|c|c|c|c|c|c|c|c|c|c|}
\hline \multirow[t]{2}{*}{ Species } & \multicolumn{10}{|c|}{ Sites } \\
\hline & $\begin{array}{l}\text { Magu } \\
\text { bay }\end{array}$ & Lamadi & Bulamba & $\begin{array}{l}\text { Baumann } \\
\text { gulf }\end{array}$ & $\begin{array}{l}\text { Shirati } \\
\text { bay }\end{array}$ & $\begin{array}{l}\text { Mori } \\
\text { bay }\end{array}$ & $\begin{array}{l}\text { Mara } \\
\text { bay }\end{array}$ & $\begin{array}{l}\text { Rubafu } \\
\text { bay }\end{array}$ & $\begin{array}{l}\text { Mwanza } \\
\text { gulf }\end{array}$ & Total \\
\hline Lates niloticus & 40.0 & 40.67 & 34.3 & 7.0 & 22.0 & 30.0 & 22.0 & 11.0 & 35.30 & 242.27 \\
\hline $\begin{array}{l}\text { Oreochromis } \\
\text { niloticus }\end{array}$ & - & 4.40 & 1.20 & 7.20 & 2.40 & - & 3.40 & 5.50 & 1.60 & 25.77 \\
\hline $\begin{array}{l}\text { Synodontis } \\
\text { victoriae }\end{array}$ & - & - & 0.03 & - & - & - & - & - & - & 0.03 \\
\hline S. afrofischeri & - & 0.05 & - & - & - & - & - & - & - & 0.05 \\
\hline $\begin{array}{l}\text { Protopterus } \\
\text { aethiopicus }\end{array}$ & 20.0 & - & - & - & - & - & - & - & - & 20.0 \\
\hline $\begin{array}{l}\text { Schilbe } \\
\text { intermedius }\end{array}$ & 1.03 & - & - & - & 0.01 & - & - & - & - & 1.04 \\
\hline $\begin{array}{l}\text { Clarias } \\
\text { gariepinus }\end{array}$ & 3.36 & - & - & - & - & - & 17.0 & 2.50 & - & 22.86 \\
\hline Bagrus docmak & 1.69 & 0.67 & - & - & 1.10 & - & - & - & 0.13 & 3.59 \\
\hline Brycinus sadleri & 0.04 & 0.13 & 0.01 & - & - & - & - & - & - & 0.18 \\
\hline B. jacksonii & 0.02 & 0.02 & 0.01 & - & - & - & - & - & - & 0.05 \\
\hline Barbus altianalis & 0.01 & - & - & - & - & - & - & - & - & 0.01 \\
\hline Labeo victorianus & - & - & - & - & - & - & - & - & 0.13 & 0.13 \\
\hline Haplochromines & 1.75 & 5.93 & 1.48 & 0.10 & 0.08 & 0.04 & 0.07 & 1.30 & 0.33 & 11.08 \\
\hline Total & 67.80 & 51.62 & 37.03 & 14.30 & 26.09 & 30.04 & 42.37 & 20.35 & 37.46 & 327.06 \\
\hline
\end{tabular}


Regarding the catch rates the results show that during the rainy season on average the catch rates of different fish species were significantly higher $\left(\mathrm{F}_{(12,12)}=2.69 ; \mathrm{P}<\right.$ $0.05)$ than during the dry season. The catch rates during the rainy season ranged from $36.25 \mathrm{~kg} / \mathrm{hr}$ at Mori Bay to $106.61 \mathrm{~kg} / \mathrm{hr}$ at Mara Bay. Other areas with high catch rates included; Bulamba (84.90 kg/hr) and Mwanza Gulf $(76.27 \mathrm{~kg} / \mathrm{hr})$. The catch rates during the dry season ranged from 14.30 $\mathrm{kg} / \mathrm{hr}$ recorded at Baumann Gulf to 67.90 $\mathrm{kg} / \mathrm{hr}$ recorded at Magu Bay. The other sites recorded the following; Lamadi (51.82 $\mathrm{kg} / \mathrm{hr}$ ), Mara Bay (42.47 kg/hr) and Mwanza Gulf $(37.56 \mathrm{~kg} / \mathrm{hr})$. The fish species which showed higher catch rates during rainy season than during dry season include; Lates niloticus, Oreochromis niloticus, Synodontis victoriae, S. afrofischeri, Schilbe intermedius and Brycinus sadleri. The haplochromines on average recorded higher catch rates during the dry season $(11.08 \mathrm{~kg} / \mathrm{hr})$ than during the rainy season $(7.72 \mathrm{~kg} / \mathrm{hr})$ but the values did not differ significantly $\left(\chi^{2}=0.60, \mathrm{df}=1, \mathrm{P}>0.05\right)$. The sites which recorded highest catch rates were; Lamadi $(5.93 \mathrm{~kg} / \mathrm{hr})$ followed by Magu Bay (1.75 kg/hr), Bulamba (1.48 $\mathrm{kg} / \mathrm{hr})$ and Rubafu Bay (1.30 kg/hr).

\section{Size structure}

Figures 1 and 2 give length frequency distribution of L. niloticus at a depth of less than $20 \mathrm{~m}$ and $20-30 \mathrm{~m}$ respectively. The results show that small individuals dominated at the depth of less than $20 \mathrm{~m}$, with modes ranging from $15 \mathrm{~cm}$ TL to 25 $\mathrm{cm}$ TL. Larger individuals were dominant in deeper waters (Fig. 2a); the mode was at $45.5 \mathrm{~cm}$ TL. Figure $2 \mathrm{~b}$ shows that both small and large individuals dominated in deeper waters whereby two modes were recorded, one at $15.5 \mathrm{~cm}$ and another one at $45.5 \mathrm{~cm}$.

\section{Physico - chemical parameters}

Table 3 shows physical and chemical parameters measured during 2002 in different sampling stations and depths. Dissolved oxygen at the surface layers ranged from 4.8 to $9.1 \mathrm{mg} / \mathrm{l}$ while at the deeper layers ranged from 4.0 to $9.1 \mathrm{mg} / \mathrm{l}$. Transparency ranged from 0 to $2.4 \mathrm{~m}$. Rubafu recorded the lowest $(0 \mathrm{~m})$ followed by Baumann Gulf $(0.7 \mathrm{~m})$. Regarding the nutrients all were within the permissible levels or values for the survival of fish (Kulekana 2003) except phosphorus in three stations where it was above the permissible value $(100 \mu \mathrm{g} / \mathrm{l})$. At Bulamba, phosphorus ranged from $119 \mu \mathrm{g} / \mathrm{l}$ (at the surface) to 163 $\mu \mathrm{g} / \mathrm{l}$ (at the bottom), at Mara Bay it ranged from $110 \mu \mathrm{g} / 1$ to $129 \mu \mathrm{g} / \mathrm{l}$ while at Mori Bay it was $133 \mu \mathrm{g} / \mathrm{l}$ at the bottom 

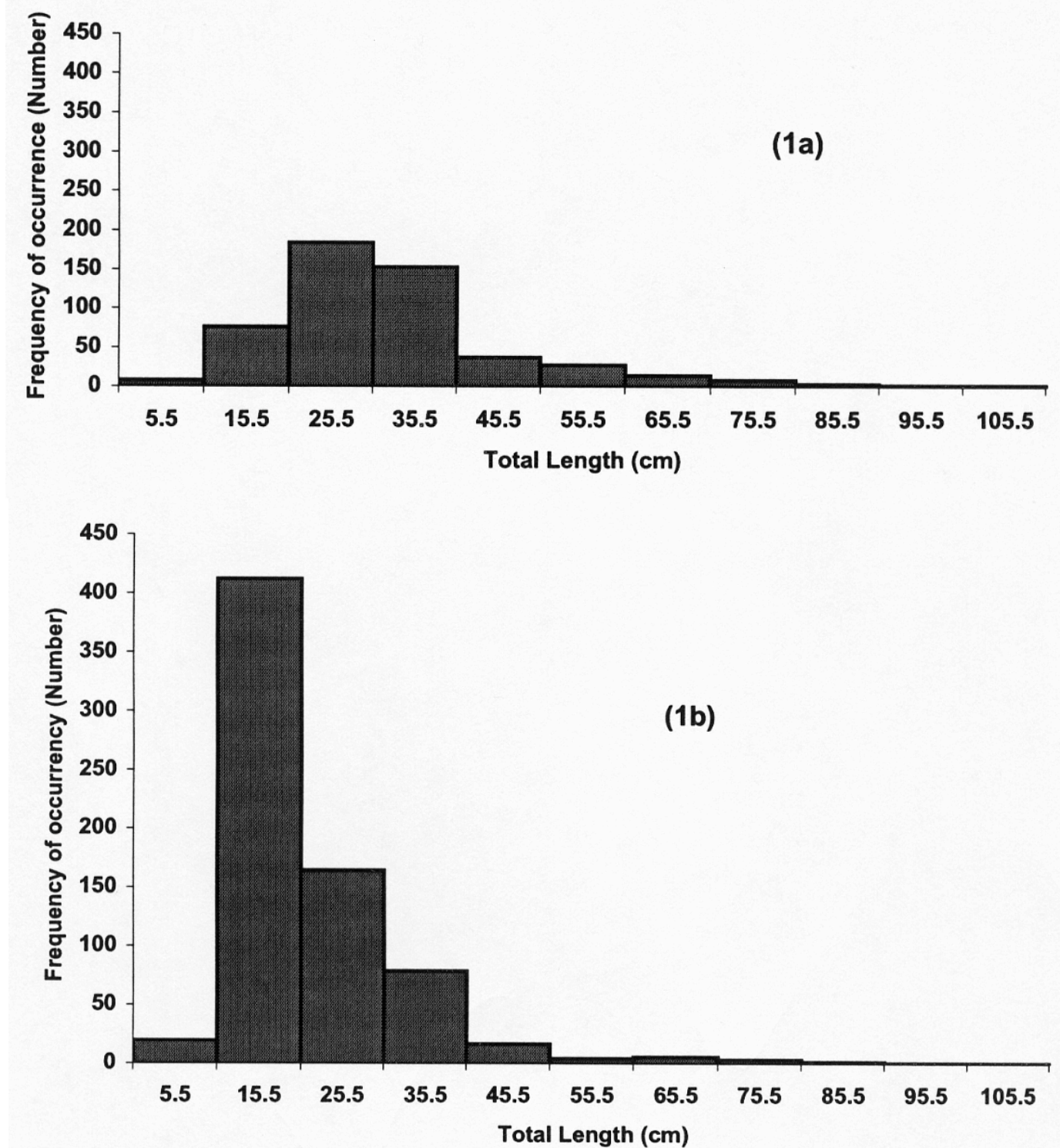

Figure 1: Length frequency distribution of L. niloticus during 2002 at $<20 \mathrm{~m}$ depth from Bulamba (a) and Mara Bay (b), L. Victoria. 

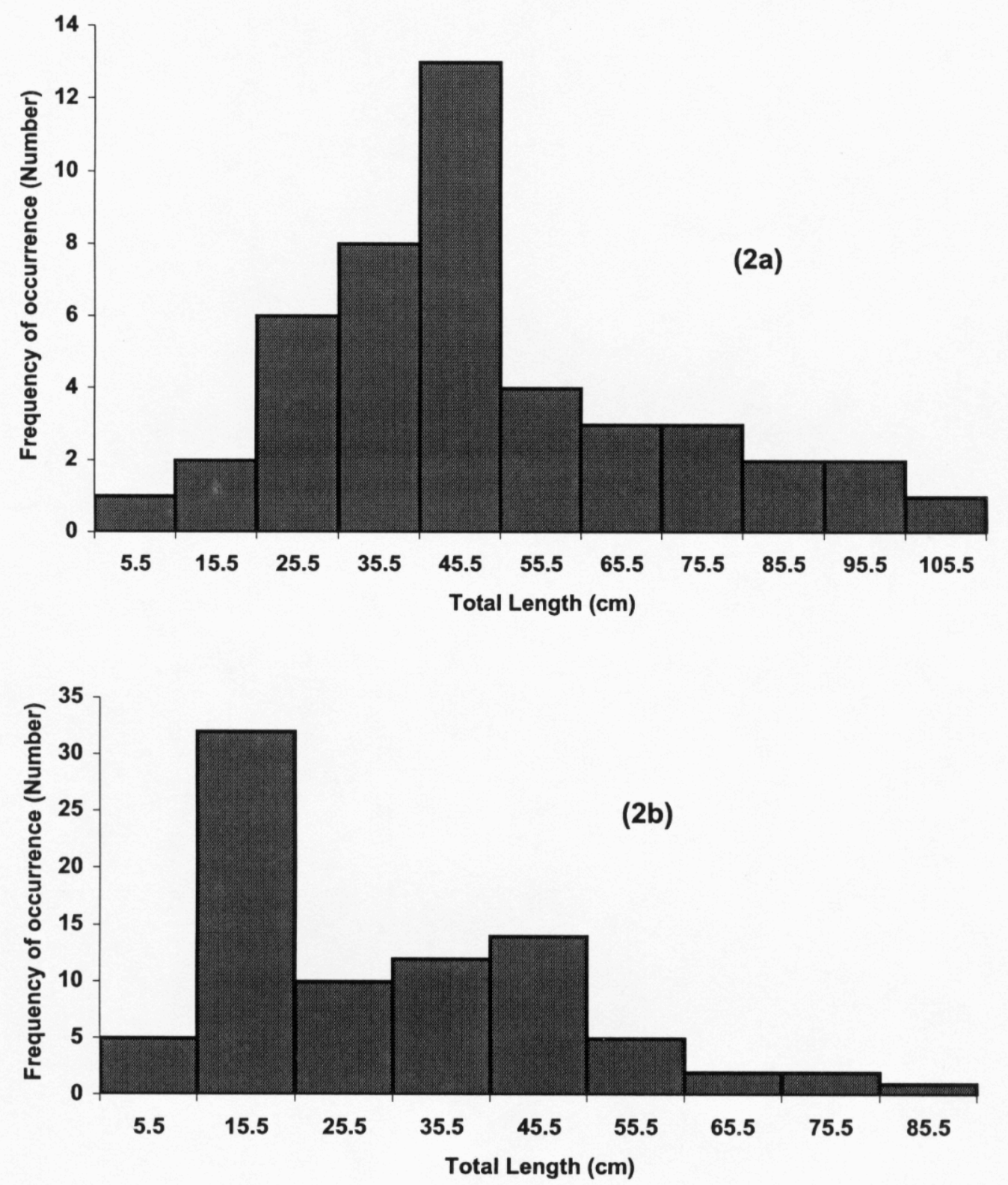

Figure 2: $\quad$ Length frequency distribution of L. niloticus during 2002 at a depth of 20-30 m from Shirati Bay (a) and Rubafu Bay (b), L. Victoria. 
Table 3: Physico-chemical characteristics of water in Lake Victoria at various sampling stations during 2002.

\begin{tabular}{lcccccccc}
\hline Parameter & $\begin{array}{c}\text { Depth } \\
(\mathrm{m})\end{array}$ & $\begin{array}{c}\mathrm{Temp} \\
\left({ }^{0} \mathrm{C}\right)\end{array}$ & $\begin{array}{c}\mathrm{DO} \\
(\mathrm{mg} / \mathrm{l})\end{array}$ & $\begin{array}{c}\mathrm{NH}_{3} \\
(\mu \mathrm{g} / \mathrm{L})\end{array}$ & $\begin{array}{c}\mathrm{NO}_{3} \\
(\mu \mathrm{g} / \mathrm{L})\end{array}$ & $\begin{array}{c}\mathrm{NO}_{2} \\
(\mu \mathrm{g} / \mathrm{L})\end{array}$ & $\begin{array}{c}\mathrm{TP} \\
(\mu \mathrm{g} / \mathrm{L})\end{array}$ & $\begin{array}{l}\text { Trans } \\
(\mathrm{m})\end{array}$ \\
\hline Lamadi & 0.5 & 24.5 & 5.5 & 234.8 & 30.4 & 8.0 & 100.0 & \\
& 6 & 24.5 & 5.3 & 256.5 & 27.7 & 4 & 101.8 & 1.6 \\
Bulamba & 0 & 24.7 & 5.7 & 101.8 & 258.7 & 95.2 & 119.5 & \\
& 10 & 24.7 & 5.7 & 89.5 & 313.2 & 103.5 & 163.7 & 1.6 \\
Bawman & 0 & 24.6 & 9.1 & 200.8 & 30.4 & 2.9 & 82.1 & \\
& & & & & & & & \\
Gulf & 3 & 24.6 & 9.1 & 259.3 & 26.6 & 1.5 & 88.7 & 0.7 \\
Mwanza & 0.5 & 25.3 & 7.4 & 141.4 & 28.5 & 5.1 & 96.9 & \\
Gulf & 15 & 25.0 & 6.6 & 455.5 & 28.3 & 2.6 & 87.0 & 1.7 \\
Mara Bay & 0 & 25.8 & 6.4 & 219.7 & 54.4 & 21.6 & 110.0 & \\
& 4 & 24.7 & 6.3 & 156.5 & 26.6 & 2.2 & 129.7 & 2.4 \\
Mori Bay & 0 & 24.6 & 4.8 & 128.2 & 21.7 & 1.8 & 98.5 & \\
& 18 & 24.5 & 4.0 & 148.0 & 20.8 & 0.7 & 133.0 & 2.4 \\
Shirati Bay & 0.5 & 25.3 & 5.8 & 128.2 & 21.7 & 4.0 & 88.7 & \\
& & & & & & & & \\
Rubafu & 15 & 24.8 & 4.4 & 120.6 & 25.95 & 2.2 & 90.3 & 2.1 \\
Bay & 0 & 25.0 & 7.3 & 186.7 & 19.0 & 1.84 & 83.7 & \\
\hline
\end{tabular}

Temp $=$ Temperature; $\mathrm{TP}=$ Total phosphorus; Trans $=$ Transparency; $\mathrm{DO}=$ Dissolved oxygen.

DISCUSSSION

Seasonal catch rates $(\mathrm{kg} / \mathrm{hr})$ and distribution of fish species in different areas

The catch rates of fish species were higher during rainy season than during dry season. The species which recorded high catch rates included, Lates niloticus, Oreochromis niloticus, Synodontis victoriae, $S$. afrofischeri, Schilbe intermedius and Brycinus sadleri. This could be explained by availability of food items in the environment and suitable breeding grounds. For example, Oreochromis niloticus feeds on phytoplankton which were also abundant during the rainy season, (ranging between 1311 individuals per millilitre and 3876 individuals per millilitre) (Mbonde et al. 2004). The species richness of phytoplankton during the rainy season was also higher (101 species) than during the dry season (43 species) (Mbonde et al. 2004). Oreochromis niloticus were abundant at Rubafu Bay and Baumann Gulf.
Transparency was lowest in these areas, 0 and $0.7 \mathrm{~m}$ respectively, a result of high abundance of phytoplankton. The phytoplankton are normally abundant during the rainy season as a result of high nutrient input into the lake due to runoff (Mugidde 1993). Some fish species which were in large quantities are catadromous using both rivers and the lake for feeding and breeding. These include Schilbe intermedius and Brycinus sadleri. During the rainy season the rivers and streams are filled with water creating a suitable environment for catadromous fish species to breed.

The abundance of the fish species in different areas varied between the rainy and dry seasons. For example, during the rainy season the highest catch rate was recorded at Mara bay $(106.61 \mathrm{~kg} / \mathrm{hr})$ while during the dry season the highest catch rate was recorded at Magu bay $(67.90 \mathrm{~kg} / \mathrm{hr})$. The differences could be attributed to the availability of food items for the fish 
species, particularly the recovering demersal haplochromines in Mara Bay, while at Magu Bay there was a high diversity of fish species during the dry season which could be preyed upon by L. niloticus (Mhitu \& Chande 2003).

The differences in the distribution of the fish species during the two seasons could also be attributed to the differences in the availability of food resources. During the rainy season there was a high abundance of the food resources hence recording the insignificant differences in the distribution of the fish species in different areas. One of the food items is the zooplankton which was reported to be more abundant during the rainy season than during the dry season (Waya \& Chande 2004), and the reverse was true during the dry season. Zooplankton are the most important converter of primary to secondary production for carnivorous invertebrates and fishes further up the food chain (Mwebaza-Ndawula 1994).

\section{Size structure}

The results indicated that small individuals dominated in shallow areas at a depth of less than $20 \mathrm{~m}$ while large ones dominated in areas with a depth greater than $20 \mathrm{~m}$. The dominance of large individuals in deeper waters could be related to differences in habitat preference according to size. One of the possible explanation could be swimming ability; larger individuals can resist high pressure and rough weather in deeper waters.

Another possible explanation for the differences in the distribution of the small and large individuals could be predation, in this case cannibalism. Predation by $L$. niloticus is fairly intense in open deep waters (Roest 1985). The individuals escaping cannibalism particularly small ones move to inshore or shallow waters where predation is less intense. Similar observations were reported by Goudswaard and Witte (1997) in Lake Victoria. The cat fish Schilbe intermedius disappeared from the offshore areas as a result of predation by
Nile perch and remained in the shallow waters.

Changes in oxygen concentrations with depth could also be a contributing factor. The dissolved oxygen showed a decreasing trend with depth (Kulekana 2003). L. niloticus is a high oxygen demanding species; therefore, small individuals to occupy deeper levels could lead to suffocation. They are active needing enough energy for growth as such they occupy shallow waters with high oxygen concentration. The large individuals could be less active hence capable of utilizing the little oxygen available at the deeper levels. For example, at Bulamba and Mara Bay the dissolved oxygen was almost the same throughout the water column and the areas were dominated by small individuals. Whereas, at Shirati Bay the concentrations of oxygen at the surface and at a depth of 15 $\mathrm{m}$ were different (5.8 and $4.4 \mathrm{mg} / \mathrm{l}$ respectively) and was dominated by larger individuals.

The study has established that the abundance of the fish species was higher during the rainy season than during the dry season and different sizes of L. niloticus were distributed according to depth, with larger ones dominating a depth greater than $20 \mathrm{~m}$. This suggests that the L. niloticus fishery should operate actively at depths greater than $20 \mathrm{~m}$ in order to catch larger or mature individuals.

\section{ACKNOWLEDGEMENTS}

We wish to express our sincere thanks to the secretariat of Lake Victoria Environment Management Project (LVEMP) particularly, the Regional Executive Secretary for funding the study. Special thanks are also extended to the Director General of Tanzania Fisheries Research Institute (TAFIRI) for providing the research vessel R.V. TAFIRI II and allowing his staff to participate in the project. 


\section{REFERENCES}

Bayona JDR, Bipa J, Kishe M, Komakoma JD and Mzighani S 2003 Aspects of fish biology and status of fish diversity in the Tanzanian littoral non-trawlable areas of Lake Victoria (Tanzania). In: Ndaro SGM and Kishimba M (eds) Proceedings of the LVEMP Tanzania 2001 Scientific Conference. Jamana Printers, Dar es Salaam, pp. 64-82.

Godswaard PC and Ligtvoet W 1988 Recent developments in the fishery for haplochromines (Pisces: Cichlidae) and the Nile perch, Lates niloticus (L.) (Pisces: Centropomidae) in Lake Victoria. In: CIFA, 1984, Committee for Inland Fisheries of Africa. Report on the third session of the Sub Committee for the Development and Management of the Fisheries of Lake Victoria. Jinja, Uganda, 4 - 5 October 1984. FAO Fisheries Report 335. pp. $101-112$.

Goudswaard P and Witte F 1985 Observations on the Nile perch ( $L$. niloticus) in Tanzania waters of Lake Victoria. FAO Fish. Rep. N0. 335: 62-67.

Goudsward PC and Witte F 1997 The catfish fauna of Lake Victoria after the Nile perch upsurge. Environmental. Biology.of Fishes. 49: 21-43.

Kaufman L 1992 Catatrophic changes in species richness in freshwater ecosystems: the lessons of Lake Victoria. Biological Science 42: 846 -858 .

Kudhongania AW 1972 Past trends and recent research on the fisheries of $\mathrm{L}$. Victoria in relation to possible future developments. African Journal of Hydrobiologia and. Fisheries, Special issue 2: 93-106.

Kulekana J 2003 Physico-chemical parameters in some satellite lakes within the Lake Victoria catchment. In: Ndaro SGM and Kishimba $\mathrm{M}$ (eds) Proceedings of the LVEMP
Tanzania $2001 \quad$ Scientific Conference. Jamana Printers, Dar es Salaam, pp. 215-233.

Meyer A, Kocher TD, Basasibwaki P and Wilson AC 1990 Monophyletic origin of Lake Victoria cichlid fishes suggested by mitochondria DNA sequences. Nature 347: 550 - 553.

Mbonde ASE, Shayo S, Sekadende B and Lyimo TJ 2004 Phytoplankton species diversity and abundance in the near-shore waters of Tanzanian side of Lake Victoria. Tanzania Journal of Science 30 (1): 71- 82.

Mhitu HA and Chande AI 2003 Food, feeding habits and trophic relationships of selected fish species in Tanzania waters of Lake Victoria. In: Ndaro SGM and Kishimba $\mathrm{M}$ (eds) Proceedings of the LVEMP Tanzania 2001 Scientific Conference. Jamana Printers, Dar es Salaam, pp. 111-116.

Mkumbo OC 2002 Assessment and management of Nile perch (Lates niloticus L.) stocks in the Tanzanian waters of Lake Victoria PhD Thesis, University of Hull, July, 2002, 275pp.

Mugidde R 1993 The increase in phytoplankton primary production and biomass in Lake Victoria (Uganda). Verh. Int. Verein. Limnol. 25: 846-849.

Mwebaza-Ndawula L 1994 Changes in relative abundance of zooplankton in northern Lake Victoria, East Africa. Hydrobiologia, 272: 259-264.

Ogutu - Ohwayo R 1988 Reproductive potential of the Nile perch, Lates niloticus (L.) and the establishment of the species in Lakes Kyoga and Victoria (East Africa). Hydrobiologia 162: 193 - 200.

Roest FC 1985 Predator - prey relations in northern Lake Tanganyika and fluctuations in the pelagic fish stocks. United Nations FAO, CIFA Symposium , SAWG/85/WPI: 1 - 
28: In: CIFA Ocassional Papers, 15: $104-129.1-28$.

Waya R and Chande AI 2004 Species composition and biomass estimates of zooplankton in some water bodies within Lake Victoria basin. Tanzania Journal of Science, 30 (1): 43-52.

Witte F, Goldschmidt T, Goudswaard PC, Ligtvoet W, Oijen M JP van and
Wanink JH 1992 Species extinction and concomitant ecological changes in Lake Victoria. Netherlands Journal of Zoology 42: 214 - 232.

Zar JH 1984 Biostatistical Analysis $2^{\text {nd }}$ Prectice Hall, Inc., Englewood Cliff, New Jersey, 718 pp. 